\title{
HEPATOPROTECTIVE EFFECT OF FORSKOLIN IN CARBON TETRACHLORIDE-INDUCED MODEL OF ACUTE LIVER INJURY \\ BY
}

Nermeen El-Agroudy ${ }^{\mathrm{a}}$, Reem N. El-Naga ${ }^{\mathrm{a}}$, Rania Shafik ${ }^{\mathrm{b}}$, Ebtehal El-Demerdash $^{\mathrm{a}}$

\section{FROM}

${ }^{a}$ Department of pharmacology and Toxicology, Faculty of Pharmacy, Ain Shams University, Cairo, Egypt

${ }^{b}$ Department of biochemistry, Faculty of Pharmacy, Ain Shams University, Cairo, Egypt

\begin{abstract}
Liver disease is one of the most common causes of death in the world. Nowadays, research studies have been focused on the development of new drugs for treatment of liver damage. Some natural products from medicinal plants have been found as potent agents for protection against liver injury induced by chemicals. Thus, it is interesting to find more effective natural products for protection against liver injury. Accordingly, the present study was designed to assess the hepatoprotective potential of a diterpenoid forskolin, isolated from the Indian plant Coleus forskohlii, at different doses in rat model with acute liver injury induced by carbon tetrachloride $\left(\mathrm{CCl}_{4}\right)$ at a dose of $1 \mathrm{ml} / \mathrm{kg}$ intraperitoneally as a mixture with corn oil. Forkolin was administered in doses of $5,10,20,40 \mathrm{mg} / \mathrm{kg}$ intraperitoneally for 7 days. Its protective effect was assessed via liver function tests and histopathological liver sections. Significant reduction in the hepatic enzymes levels was found in animals treated with forskolin at a dose of $10 \mathrm{mg} / \mathrm{kg}$ as well as restoration of hepatocellular architecture. Therefore, treatment with forskolin showed preventive effect against $\mathrm{CCl}_{4}$-induced liver damage.
\end{abstract}

Keywords: Forskolin; Carbon tetrachloride; Hepatoprotective; Rats. 


\section{INTRODUCTION}

Liver disease is a serious health problem throughout the world. A special interest in lowering liver damage arises since liver is a vital organ that plays a pivotal role in metabolism and detoxification of various endogenous and exogenous harmful substances (Yang et al., 2010). Many hepatotoxicants are known to cause liver injury in humans, such as viruses, fungal products, bacterial metabolites, minerals, environmental pollutants and chemotherapeutic agents (Wang et al., 2008). Despite new advances in hepatology, there is a lack of effective therapeutic strategies or specific medicines for the protection against hepatic disorders (Wu et al., 2007). Therefore, herbal medicines that possess hepatoprotective effects have attracted the attention of many researchers in recent years (Hermenean et al., 2012; Kang et al., 2013; Tipoe et al., 2010; Zhang et al., 2013).

Carbon tetrachloride $\left(\mathrm{CCl}_{4}\right)$, a potent hepatotoxin, is widely used as a chemical inducer of experimental liver injury (Domitrovic and Jakovac, 2010). $\mathrm{CCl}_{4}$ metabolism begins with the highly reactive trichloromethyl free radicals $\left(\mathrm{CCl}_{3} \cdot\right)$ by the action of the liver reduced nicotinamide adenine dinucleotide phosphate (NADPH) cytochrome P450 enzyme system (McCay et al., 1984). These free radicals are believed to cause lipid peroxidation, and the breakdown of cellular membranes (Manibusan et al., 2007).

Forskolin, a labdane diterpene is the main active ingredient in the ayurvedic herb Coleus forskohlii (Labatiae) that has been used in India since ancient times. The root portion of the plant has been traditionally used for medicinal purposes and contains the active constituent, forskolin. Historically, it has been used to treat hypertension, congestive heart failure, eczema, colic, respiratory disorders, painful urination, insomnia, and convulsions. Clinical studies have justified these traditional uses and indicate its therapeutic potential in asthma, angina, glaucoma, psoriasis, and prevention of cancer metastases (Patel, 2010; Wagh et al., 2012). These properties encouraged us to investigate its hepatoprotective effect in a $\mathrm{CCl}_{4}$-induced acute hepatotoxicity model.

\section{MATERIALS AND METHODS}

\section{Materials}

Forskolin was purchased from LC Laboratories (Woburn, MA, USA). It was dissolved in a mixture of dimethyl sulfoxide (DMSO) and saline. All other chemicals were purchased from Sigma-Aldrich (St. Louis, MO, USA).

\section{Animals and experimental protocol}

The studies were conducted in accordance with ethical guidelines of Ain Shams University, Egypt. Male albino rats weighing 150-250 g rats were used in this study. They were supplied by Nile Co. for Pharmaceutical and Chemical industries, Egypt and housed in an air-conditioned atmosphere at $22 \pm 2{ }^{\circ} \mathrm{C}$, under a $12 \mathrm{~h}$ light-dark cycle and provided with rodent chow and water ad libitum.

Forty-eight animals were randomly divided into six groups of eight rats each. Group I served as normal control, receiving vehicles only for 7 days. Groups II-V were given forskolin $(5,10,20$ and $40 \mathrm{mg} / \mathrm{kg} \mathrm{IP}$, respectively) dissolved in a DMSO/saline solution for 7 days and on the 7th day; after one hour of forskolin injection, a single dose of $\mathrm{CCl}_{4}(1 \mathrm{ml} / \mathrm{kg}, \mathrm{IP}, 1: 1$ mixture with corn oil) was given. Group VI served as 
disease group, receiving vehicles for 7 days and on the 7th day; a single dose of $\mathrm{CCl}_{4}$ $\left(1 \mathrm{ml} / \mathrm{kg}\right.$, IP, 1:1 mixture with corn oil) was given. $24 \mathrm{~h}$ after $\mathrm{CCl}_{4}$ injection, Blood samples were collected from the retro-orbital plexus and allowed to clot. Serum was separated by centrifugation at $3000 \mathrm{rpm}$ for $10 \mathrm{~min}$, then stored at $-20^{\circ} \mathrm{C}$. Rats were sacrificed and liver tissues were dissected, washed and placed in $10 \%$ formalin for histopathological examination.

\section{Assessment of liver function tests}

The levels of ALT and AST were measured following the commercial kit's instructions (Spectrum diagnostics, Egypt).

\section{Histopathological examination}

For light microscopy, liver specimens were fixed in $10 \%$ formalin and embedded in paraffin. Sections of 4 um thickness were cut, stained with hematoxylin and eosin and subjected to photomicroscopic examination.

\section{Statistical analysis}

Data are presented as mean \pm standard deviation (SD). Statistical analysis was performed using one-way analysis of variance (ANOVA) followed by Tukey-Kramer as a post hoc test. The 0.05 level of probability was used as the criterion for significance. All statistical analyses were performed using Instat software package (version 3.06).

\section{RESULTS}

\section{Effect of Forskolin on ALT and AST in serum}

Compared to the control group, $\mathrm{CCl}_{4}$ induced a significant increase in serum ALT and AST levels reaching 160 and 21.9 fold respectively. Concurrent administration of 5,20 and $40 \mathrm{mg} / \mathrm{kg}$ Forskolin with $\mathrm{CCl}_{4}$ did not show any significantly decrease in ALT and AST levels as compared to $\mathrm{CCl}_{4}$ group. However, the $10 \mathrm{mg} / \mathrm{kg}$ dose of forskolin showed a significant decrease in ALT and AST reaching $18.6 \%$ and $25.2 \%$ respectively as compared to the $\mathrm{CCl}_{4}$ group (Table 1). 
Table 1. Effect of different doses of Forskolin on serum ALT and AST levels.

\begin{tabular}{|c|c|c|}
\hline Groups & $\operatorname{ALT}(\mathbf{U} / \mathbf{L})$ & $\operatorname{AST}(\mathbf{U} / \mathbf{L})$ \\
\hline Control & $8.56 \pm 1.55^{b}$ & $58.63 \pm 3.02^{\mathrm{b}}$ \\
\hline $\mathrm{CCl}_{4}$ & $1372.8 \pm 256.35^{\mathrm{a}}$ & $1282.08 \pm 115.42^{\mathrm{a}}$ \\
\hline $\mathrm{CCl}_{4}+$ Forskolin $(5 \mathrm{mg} / \mathrm{kg})$ & $1250.67 \pm 319.91^{a}$ & $870.2 \pm 213.25^{a}$ \\
\hline $\mathrm{CCl}_{4}+$ Forskolin $(10 \mathrm{mg} / \mathrm{kg})$ & $254.67 \pm 37.166^{b}$ & $323.6 \pm 89.46^{b}$ \\
\hline $\mathrm{CCl}_{4}+$ Forskolin $(20 \mathrm{mg} / \mathrm{kg})$ & $1763.33 \pm 157.38^{a}$ & $1405.25 \pm 391.88^{a}$ \\
\hline $\mathrm{CCl}_{4}+$ Forskolin $(40 \mathrm{mg} / \mathrm{kg})$ & $936 \pm 173.94^{a}$ & $1033.17 \pm 165.05^{a}$ \\
\hline
\end{tabular}

* Data are the mean \pm SD $(n=6)$. a or b: Significantly different from control or $\mathrm{CCl}_{4}$ group, respectively at $\mathrm{P}<\mathbf{0 . 0 0 1}$ using ANOVA followed by Tukey-Kramer as a post-hoc test.

\section{Histopathological findings}

Liver sections from control group stained with $\mathrm{H} \& \mathrm{E}$ showed normal hepatic architecture (Figure 1A). $\mathrm{CCl}_{4}$ group showed centrilobular necrosis with ballooning degeneration in the hepatocytes associated with dilatation in the central vein (Figure 1B). Pretreatment with $5 \mathrm{mg} / \mathrm{kg}, 20 \mathrm{mg} / \mathrm{kg}$ and $40 \mathrm{mg} / \mathrm{kg}$ Forskolin failed to reduce the extensive hepatocellular damage caused by $\mathrm{CCl}_{4}$. Liver sections from those 3 groups showed centrilobular necrosis with ballooning degeneration in diffuse manner all over the hepatocytes in association with congestion in the portal vein (Figure $1 \mathbf{C , E}, \mathbf{F}$ ). However, pretreatment with $10 \mathrm{mg} / \mathrm{kg}$ Forskolin dose significantly reduced these alterations as liver sections only showed ballooning degeneration in some of the hepatocytes with dilatation in the central vein (Figure 1 D). A histopathologist graded these histopathological findings (Table 2). 
Table 2. Histopathological grading.

\begin{tabular}{|c|c|c|c|}
\hline \multirow[b]{2}{*}{ Groups } & \multicolumn{3}{|c|}{ Histopathological Alteration } \\
\hline & $\begin{array}{l}\text { Centrilobular } \\
\text { necrosis }\end{array}$ & $\begin{array}{l}\text { Ballooning } \\
\text { degeneration }\end{array}$ & $\begin{array}{l}\text { Dilatation of central } \\
\text { vein }\end{array}$ \\
\hline Control & - & - & - \\
\hline $\mathbf{C C l}_{4}$ & +++ & ++ & ++ \\
\hline $\begin{array}{l}\mathrm{CCl}_{4}+\text { Forskoli } \\
\text { n }(5 \mathrm{mg} / \mathrm{kg})\end{array}$ & ++ & ++ & + \\
\hline $\begin{array}{c}\mathrm{CCl}_{4}+\text { Forskoli } \\
\text { n }(10 \mathrm{mg} / \mathrm{kg})\end{array}$ & - & ++ & ++ \\
\hline $\begin{array}{c}\mathrm{CCl}_{4}+\text { Forskoli } \\
\text { n }(20 \mathrm{mg} / \mathrm{kg})\end{array}$ & +++ & ++ & + \\
\hline $\begin{array}{c}\mathrm{CCl}_{4}+\text { Forskoli } \\
\text { n (40 mg/kg) }\end{array}$ & +++ & +++ & ++ \\
\hline
\end{tabular}

+++ (Severe), ++ (Moderate), + (Mild), - (Nil)

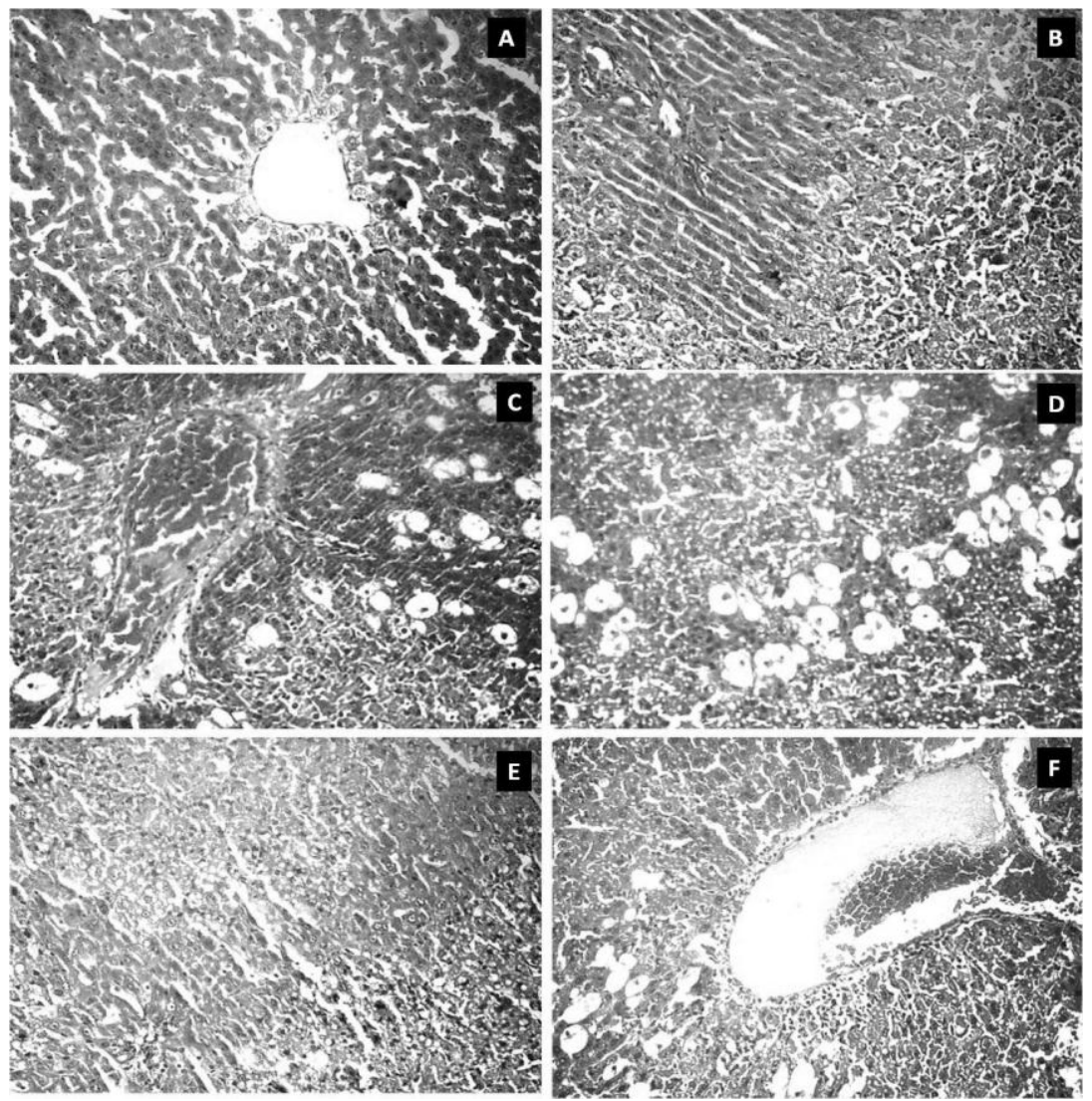

Figure 1. Histopathological analysis of rat liver sections using H\&E (x40):

A: Control group. B: $\mathrm{CCl}_{4}$ group. C: Group pretreated with $5 \mathrm{mg} / \mathrm{kg}$ Forskolin. D: Group pretreated with $10 \mathrm{mg} / \mathrm{kg}$ Forskolin. E: Group pretreated with $20 \mathrm{mg} / \mathrm{kg}$ Forskolin. F: Group pretreated with $40 \mathrm{mg} / \mathrm{kg}$ Forskolin. 


\section{DISCUSSION}

Acute and chronic liver diseases constitute a global concern, and it is mostly induced by viral hepatitis, alcoholism, iron overload or drug toxicity. Among these types of liver injuries, there is consistent evidence of enhanced production of free radicals and/or a significant decrease in antioxidant defense mechanisms (Hoek and Pastorino, 2002). Many drugs have been used in the treatment of liver damage. However, the medical treatments for acute and chronic liver diseases are often difficult to handle and have limited efficacy. Thus, there is a need to explore new medicines with high efficacy for the protection against liver diseases.

$\mathrm{CCl}_{4}$ has been widely used for experimental induction of hepatic fibrosis in rats (Hernandez-Munoz et al., 1990; Pierce et al., 1987). $\mathrm{CCl}_{4}$ undergo metabolism by cytochrome P450 2E1 leading to production of free radicals which cause lipid peroxidation of the hepatocellular membrane, followed by inflammatory cytokines release and, eventually, hepatocellular damage (Recknagel et al., 1989; Weber et al., 2003). The later was evidenced by the significant elevation in the serum levels of the aminotransferases enzymes ALT and AST, because these enzymes are cytoplasmic and are released into the blood after cellular damage (Recknagel et al., 1989).

Results showed that a significant increase in the level of ALT and AST in $\mathrm{CCl}_{4}$-treated rats. The level of ALT and AST decreased significantly in administration of $10 \mathrm{mg} / \mathrm{kg}$ dose of forskolin only. However, other doses failed to protect the liver against $\mathrm{CCl}_{4}$-induced toxicity as evidenced by the high serum levels of ALT and AST. These biochemical results were confirmed by the histopathological findings. Our results were in accordance with a previous study which showed that forskolin reduced serum ALT levels and preserved hepatic architecture in a mouse model of liver ischemia/reperfusion injury (Ji et al., 2012).

Based on the previous findings, this study confirms that forskolin, indeed, has a hepatoprotective effect against $\mathrm{CCl}_{4}$-induced acute hepatotoxicity. The anti-oxidant and anti-inflammatory effects reported in previous studies on forskolin might be the reason for its hepatoprotective effect (Irie et al., 2001; Kamata et al., 1996; Niaz and Singh, 1999).

\section{REFERENCES}

Domitrovic, R., Jakovac, H., (2010): Antifibrotic activity of anthocyanidin delphinidin in carbon tetrachloride-induced hepatotoxicity in mice. Toxicology 272, 1-10.

Hermenean, A., Popescu, C., Ardelean, A., Stan, M., Hadaruga, N., Mihali, C.V., Dinischiotu, A., (2012): Hepatoprotective effects of Berberis vulgaris L. extract/ $\beta$ cyclodextrin on carbon tetrachloride-induced acute toxicity in mice.International journal of molecular sciences, 13(7), 9014-9034.

Hernandez-Munoz, R., Diaz-Munoz, M., Suarez, J., Chagoya de Sanchez, V., (1990): Adenosine partially prevents cirrhosis induced by carbon tetrachloride in rats. Hepatology 12, 242-248.

Hoek, J.B., Pastorino, J.G., (2002): Ethanol, oxidative stress, and cytokine-induced liver cell injury. Alcohol 27, 63-68.

Irie, K., Fujii, E., Ishida, H., Wada, K., Suganuma, T., Nishikori, T., Yoshioka, T., Muraki, T., (2001): Inhibitory effects of cyclic AMP elevating agents on 
lipopolysaccharide (LPS)-induced microvascular permeability change in mouse skin. Br J Pharmacol 133, 237-242.

Ji, H., Shen, X.D., Zhang, Y., Gao, F., Huang, C.Y., Chang, W.W., Lee, C., Ke, B., Busuttil, R.W., Kupiec-Weglinski, J.W., (2012): Activation of cyclic adenosine monophosphate-dependent protein kinase a signaling prevents liver ischemia/reperfusion injury in mice. Liver Transpl 18, 659-670.

Kang, M. C., Kang, S. M., Ahn, G., Kim, K. N., Kang, N., Samarakoon, K. W., Oh, M. C., Lee, J. S. Jeon, Y. J. (2013): Protective effect of a marine polyphenol, dieckol against carbon tetrachloride-induced acute liver damage in mouse. Environmental toxicology and pharmacology, 35(3), 517-523

Kamata, H., Tanaka, C., Yagisawa, H., Hirata, H., (1996): Nerve growth factor and forskolin prevent $\mathrm{H} 2 \mathrm{O} 2$-induced apoptosis in PC12 cells by glutathione independent mechanism. Neurosci Lett 212, 179-182.

Manibusan, M.K., Odin, M., Eastmond, D.A., (2007): Postulated carbon tetrachloride mode of action: a review. J Environ Sci Health $\mathrm{C}$ Environ Carcinog Ecotoxicol Rev 25, 185-209.

McCay, P.B., Lai, E.K., Poyer, J.L., DuBose, C.M., Janzen, E.G., (1984): Oxygenand carbon-centered free radical formation during carbon tetrachloride metabolism. Observation of lipid radicals in vivo and in vitro. $\mathrm{J}$ Biol Chem $259,2135-2143$.

Niaz, M.A., Singh, R.B., (1999): Modulation of free radical stress in human red blood cell membrane by forskolin and the prospects for treatment of cardiovascular disease and diabetes. Cell Mol Biol (Noisy-le-grand) 45, 1203-1207.

Patel, M.B., (2010): Forskolin: A Successful Therapeutic Phytomolecule. East and Central African Journal of Pharmaceutical Sciences 13, 25-32.

Pierce, R.A., Glaug, M.R., Greco, R.S., Mackenzie, J.W., Boyd, C.D., Deak, S.B., (1987): Increased procollagen mRNA levels in carbon tetrachloride-induced liver fibrosis in rats. J Biol Chem 262, 1652-1658.

Recknagel, R.O., Glende, E.A., Jr., Dolak, J.A., Waller, R.L., (1989): Mechanisms of carbon tetrachloride toxicity. Pharmacol Ther 43, 139-154.

Tipoe, G.L., Leung, T.M., Liong, E.C., Lau, T.Y., Fung, M.L., Nanji, A.A., (2010): Epigallocatechin-3-gallate (EGCG) reduces liver inflammation, oxidative stress and fibrosis in carbon tetrachloride $\left(\mathrm{CCl}_{4}\right)$-induced liver injury in mice. Toxicology 273, 45-52.

Wagh, V.D., Patil, P.N., Surana, S.J., Wagh, K.V., (2012): Forskolin: Upcoming antiglaucoma molecule. J Postgrad Med 58, 199-202

Wang, T., Sun, N.L., Zhang, W.D., Li, H.L., Lu, G.C., Yuan, B.J., Jiang, H., She, J.H., Zhang, C., (2008): Protective effects of dehydrocavidine on carbon tetrachloride-induced acute hepatotoxicity in rats. J Ethnopharmacol 117, 300-308.

Weber, L.W., Boll, M., Stampfl, A., (2003): Hepatotoxicity and mechanism of action of haloalkanes: carbon tetrachloride as a toxicological model. Crit Rev Toxicol 33, 105-136. 
Wu, Y., Li, L., Wen, T., Li, Y.Q., (2007): Protective effects of echinacoside on carbon tetrachloride-induced hepatotoxicity in rats. Toxicology 232, 50-56.

Yang, J., Li, Y., Wang, F., Wu, C., (2010): Hepatoprotective effects of apple polyphenols on $\mathrm{CCl}_{4}$-induced acute liver damage in mice. J Agric Food Chem $58,6525-6531$.

Zhang, S., Lu, B., Han, X., Xu, L., Qi, Y., Yin, L., Youwei, X., Yanyan, Z., Kexin, L., Peng, J. (2013): Protection of the flavonoid fraction from Rosa laevigata Michx fruit against carbon tetrachloride-induced acute liver injury in mice. Food and Chemical Toxicology, 55, 60-69. 


\section{تأثثر الكبد الوقائي لعقار "فورسكولين" في نموذج تجريبي لإصابة الكبد الحادة الناجمة عن رابع} كلوريد الكربون فيوني

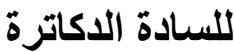

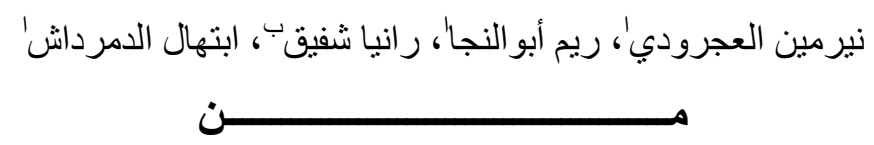

'كلية الصيدلة، قسم الأدوية والسموم، جامعة عين شمس، القاهرة، مصر

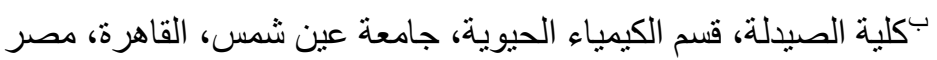

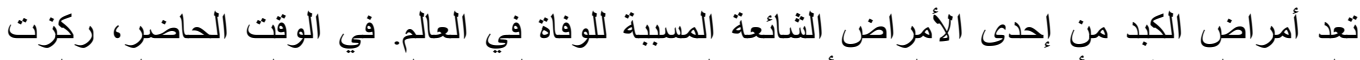

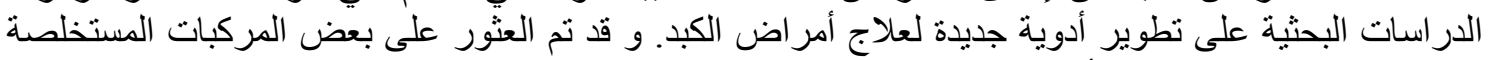

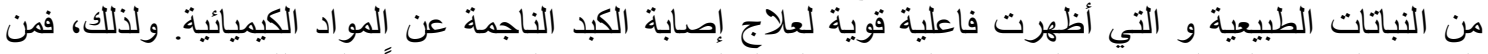

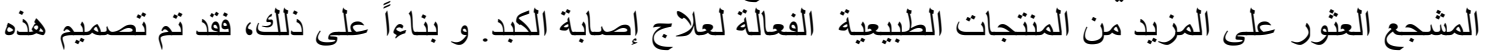

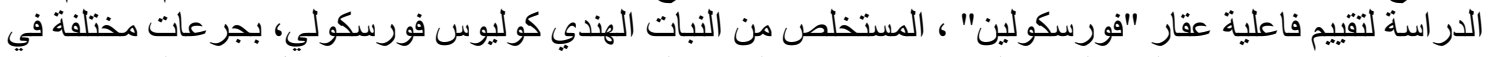

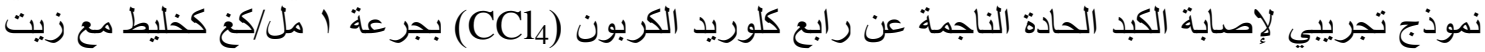

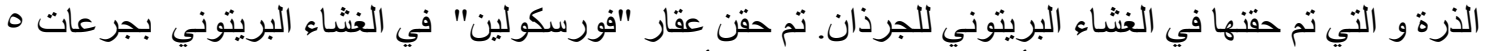

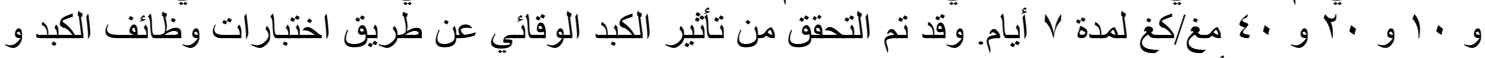

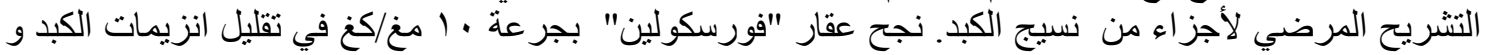

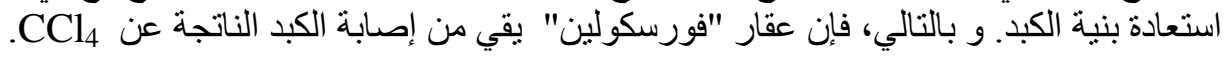

